\title{
Composition of ultraphytoplankton in the central North Atlantic
}

\author{
W. K. W. Li \\ Biological Oceanography Division, Bedford Institute of Oceanography, Dartmouth, Nova Scotia, Canada B2Y 4A2
}

\begin{abstract}
In the central North Atlantic Ocean, the ultraphytoplankton averaged over depth and season comprises $78 \%$ Prochlorococcus spp., $12 \%$ Synechococcus spp. and $10 \%$ eukaryotic algae by numbers. However, on the basis of light scatter (a substitute for carbon biomass), the average percentages are 11,2 and $87 \%$ respectively. On the basis of red fluorescence (a substitute for chlorophyll biomass), the average percentages are 28,11 and $61 \%$ respectively. On the basis of primary productivity, the average percentages are 19,13 and $68 \%$ respectively. Thus, eukaryotic algae dominate the biomass and productivity of ultraphytoplankton.
\end{abstract}

KEY WORDS: Chlorophyll Cyanobacteria Flow cytometry Prochlorophytes - Ultraphytoplankton

\section{INTRODUCTION}

In oligotrophic oceans, most, though not all, of the phytoplankton are small and might be termed ultraplankton (sensu Shapiro \& Guillard 1986). Of these, prochlorophytes (Prochlorococcus spp.) are generally the most abundant, cyanobacteria (Synechococcus spp.) rank second, and the taxonomically diverse group of eukaryotic algae (Prasinophyceae, Prymnesiophyceae, Chrysophyceae, Pelagophyceae, Bacillariophyceae and others) number the least. On the other hand, on average, prochlorophytes (ca $0.7 \mu \mathrm{m}$ ) are smaller than cyanobacteria (ca $1 \mu \mathrm{m}$ ), which in turn are smaller than many, though not all, of the eukaryotic ultraplankton (ca 0.7 to $5 \mu \mathrm{m}$ ).

To rank these 3 ultraphytoplankton groups in order of dominance by carbon biomass $\left(\mu \mathrm{g} \mathrm{C} \mathrm{ml}^{-1}\right)$, chloro-

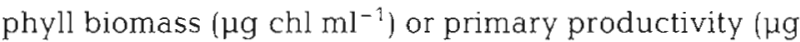
$\mathrm{C} \mathrm{ml} \mathrm{m}^{-1} \mathrm{~h}^{-1}$ ), it is necessary to weight the mean cellular carbon ( $\mu \mathrm{g} \mathrm{C}$ cell ${ }^{-1}$ ), mean cellular chlorophyll ( $\mu \mathrm{g} \mathrm{chl}$ cell ${ }^{-1}$ ) or mean cellular carbon uptake $\left(\mu \mathrm{g} \mathrm{C}\right.$ cell $\left.^{-1} \mathrm{~h}^{-1}\right)$ of each group by the numerical abundance (cells $\mathrm{ml}^{-1}$ ). Since abundance and cell size are ranked in opposing order, it is not obvious how biomass and productivity would be ranked. Simply stated, one large cell can be viewed as the equivalent of many small cells (Goldman 1988, Margalef 1994).
For ultraphytoplankton, flow cytometric analysis and sorting are able to yield all the information necessary for an initial, though inexact, solution to this problem (Li et al. 1993b, Li 1994a, b). Measurements can be routinely made of cell abundance, light scatter per cell (a substitute for volume per cell, and thus also a substitute for carbon per cell) and red fluorescence per cell (a substitute for chlorophyll a per cell). Less routinely, measurements can also be made of ${ }^{14} \mathrm{C}$ uptake per cell by flow sorting phytoplankton that have been radiolabelled over the course of standard incubation experiments (Li 1994b). The greatest uncertainty in this approach lies in the use of substitute variables because they are not necessarily related in a linear fashion to the variables of true interest. In this paper, the methods and assumptions described recently ( $\mathrm{Li}$ et al. 1993b, Li 1994a, b) are used to rank the importance of Prochlorococcus, Synechococcus, and eukaryotic ultraphytoplankton in the central North Atlantic Ocean.

\section{METHODS}

Phytoplankton were taken from Niskin bottles deployed on 27 hydrocasts made in 1992 (September to October) and in 1993 (May to June) on transects from 


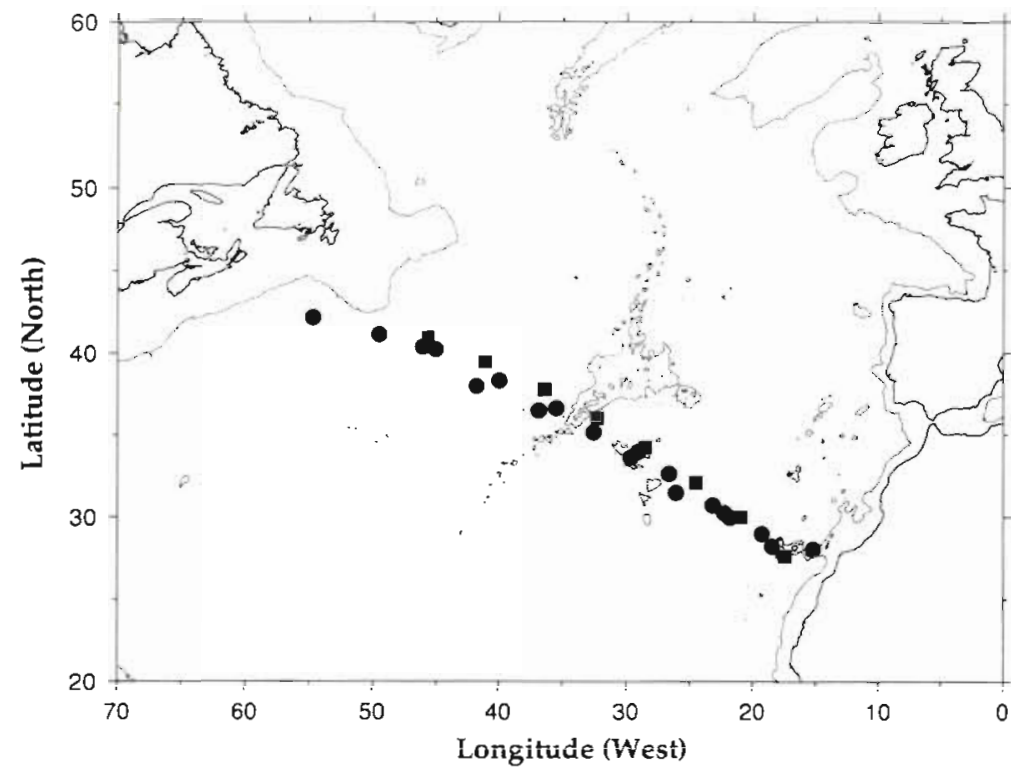

Fig 1. Locations where samples were collected in September-October 1992 (O) and in May-June 1993 (ם). Dotted lines indicate 2000 m bathymetric contour

the continental slope in the west to the Canary Islands in the east (Fig. 1)

Measurements of cell abundance, fluorescence per cell, and forward (narrow angle) light scatter per cell were made by flow cytometric analysis based on $488 \mathrm{~nm}$ excitation light (FACSort[tm], Becton Dickinson). Samples of 0.25 to $0.50 \mathrm{ml}$ were freshly analysed shortly after removal from the Niskin bottles. Fluorescence at wavelengths longer than $650 \mathrm{~nm}$ (FL3 instrument channel) was ascribed to chlorophyll a; fluorescence centred at $585 \pm 21 \mathrm{~nm}$ was ascribed to phycoerythrin. Light scattered over a range of halfcone angles from $<1$ to $10^{\circ}$ was collected by a solid state silicon detector with spectral response from 300 to $1100 \mathrm{~nm}$ (specifications from manufacturer). Measurements of fluorescence and light scatter were collected using logarithmic amplification and recorded in relative units in a 4 -decade range spanned by 256 channels. Data were extracted from listmode format using LYSYS II[tm] software (Becton Dickinson). To ensure that only phytoplankton were enumerated, particles with red fluorescence weaker than that emitted by Prochlorococcus spp. were rejected. The identification of Prochlorococcus spp., Synchococcus spp., and eukaryotic ultraphytoplankton from cytometric signatures was based on interactive analysis of multiple bivariate scat- terplots as described explicitly by Olson et al. (1993).

In flow cytometric analyses of phytoplankton, it is common practice to regard forward light scatter as an index of cell size (Olson et al. 1993). Light scatter is a measurement of particle cross sectional area, but this measurement may also be influenced by particle shape and refractive index. Nevertheless, Olson et al. (1989) have demonstrated a strong empirical correlation between forward light scatter and Coulter volume using a wide variety of algae including calcifying strains of coccolithophores. These authors suggested that, at the low angles used by the flow cytometer to measure forward scatter, the influences of cell shape and retractive index are minor. Relative measurements of forward light scatter were here calibrated using beads of various size
1992
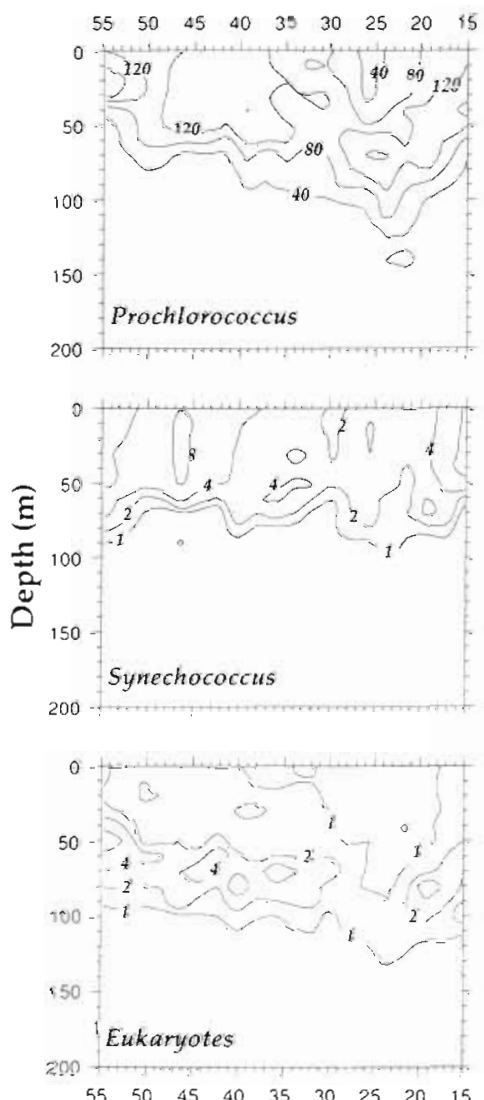

Longitude (West)

Fig. 2. Prochlorococcus spp., Synechococcus spp., and eukaryotic algae. Depth and longitudinal distributions of ultraphytoplankton abundance $\left(10^{3}\right.$ cells $\left.\mathrm{ml}^{-1}\right)$ in September-October 1992 (left column) and in May-June 1993 (right column)

\section{3}
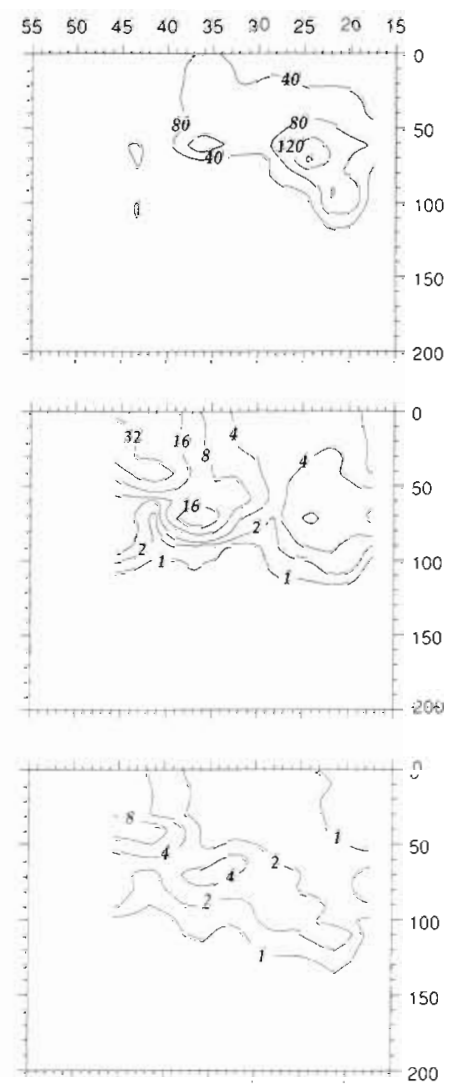
and material composition (Polysciences \#18859, 18860, 18604, 18861, 18862; Duke Scientific \#R600, R0100, R0290, 268, 361; Coulter fluorospheres $5.43 \mu \mathrm{m}$, $8.55 \mu \mathrm{m}, 9.64 \mu \mathrm{m})$. Expressed as equivalent spherical diameter, the useful range encompassed by the light scatter measurements in the present study was from 0.44 to $6.8 \mu \mathrm{m}$. Autofluorescing cells having an equivalent spherical diameter larger than $6.8 \mu \mathrm{m}$, if present in a sample of $\leq 0.5 \mathrm{ml}$, were detected, but their numbers were collectively accumulated in the highest data acquisition channel regardless of size. Here, equivalent spherical diameter may be thought of in the following way: a particle (cell) of undetermined shape and undetermined refractive index has scattered light in such a way that the intensity is the same as that of a certain size bead which has a spherical shape and a synthetic composition. That 'certain size' is not necessarily the same as cell diameter estimated by microscopy.

Cell-specific rates of ${ }^{14} \mathrm{C}$ uptake were determined on cells sorted by flow cytometry after simulated in situ $8 \mathrm{~h}$ incubations with added $\mathrm{NaH}^{14} \mathrm{CO}_{3}$. Details of the protocol have been described (Li 1994).

\section{RESULTS AND DISCUSSION}

A seasonal difference was evident in the abundance of each ultraphytoplankton group, but the major distributional features across $40^{\circ}$ of longitude were broadly similar between seasons (Fig. 2). Subsurface maxima were conspicuous for Prochlorococcus and eukaryotes across much of the central ocean, but the depth of the maxima deepened from west to east (which was also a north to south excursion of ca $10^{\circ}$ latitude), except in the vicinity of the Canary Islands where the maxima became shallower. Synechococcus tended to be uniformly distributed in the upper mixed layer with abundances higher in the west than in the east. These oceanwide observations at 2 times of the year (Fig. 2) complement and augment other North Atlantic data (Olson et al. 1990a, b). Based on these observations, it appears that, in spite of spatial variability, there are persistent features that characterize the depth and seasonal distributions of ultraphytoplankton in the central North Atlantic.

These features are summarized as transectwide averages and indicated in depth profiles (Fig. 3) representing late summer-early fall (1992) and late spring-early summer (1993). A most notable feature was the increase of Pro- chlorococcus in late summer coincident with decreases of both Synechococcus and eukaryotes. The late summer situation approached what Campbell \& Vaulot (1993) suggest is typical for subtropical open-ocean regions: namely, that Prochlorococcus is abundant in the surface mixed layer at a concentration more than half that at the sub-surface maximum and that the depth-integrated abundance of Prochlorococcus greatly exceeds that of Synechococcus. Across the central North Atlantic in late spring (1993), average depthintegrated abundances $\left(10^{6}\right.$ cells $\left.\mathrm{cm}^{-2}\right)$ were 462 for Prochlorococcus, 85 for Synechococcus, and 29 for eukaryotes. However, in late summer (1992), there were more Prochlorococcus (1031), fewer Synechococcus (32), and fewer eukaryotes (21).

The central question is now posed: which of the 3 groups dominates the ultraphytoplankton? There are 4

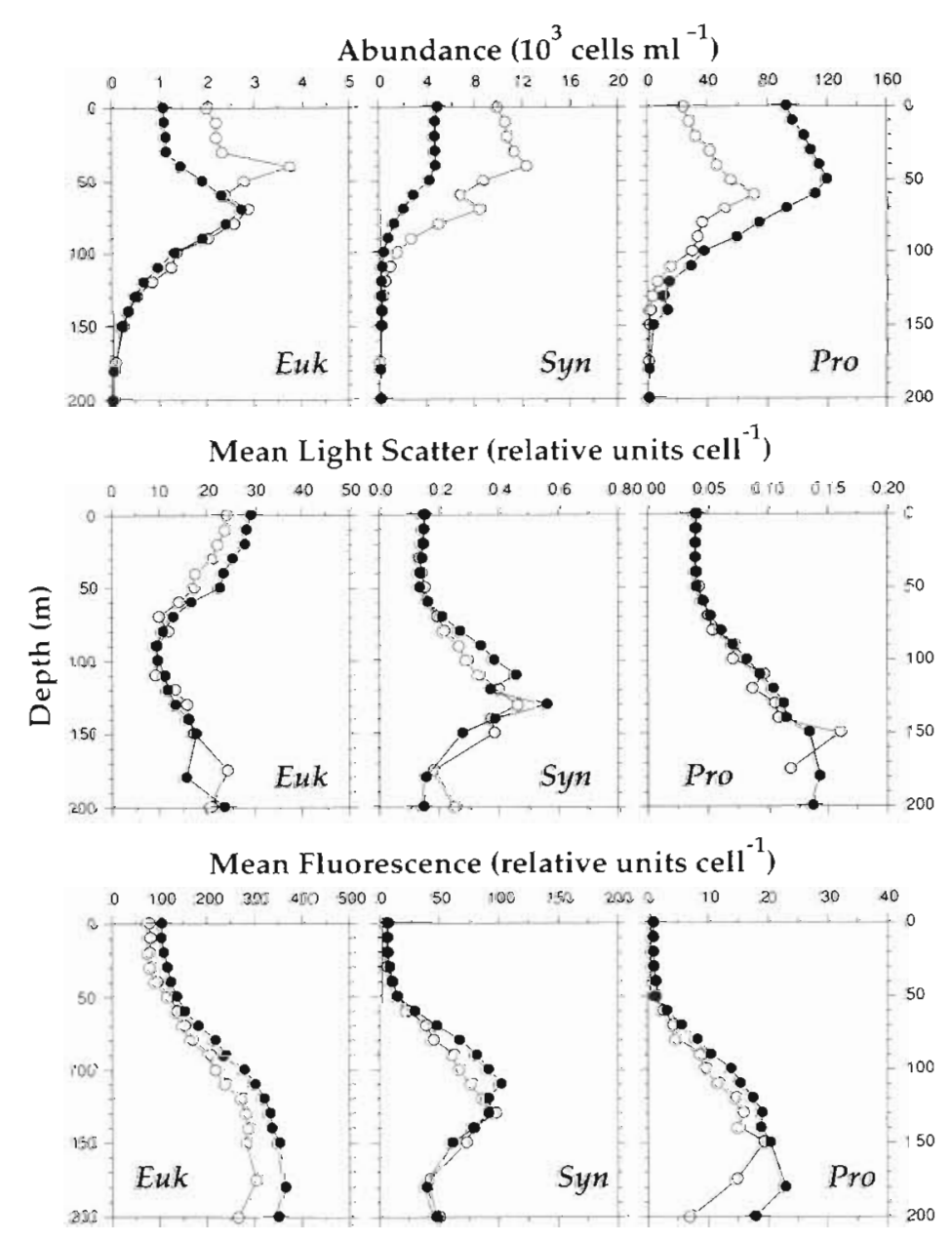

Fig. 3. Eukaryotic algae (Euk), Synechococcus spp. (Syn) and Prochlorococcus spp. (Pro). Transect-wide mean values for ultraphytoplankton in September-October 1992 ( ) and in May-June 1993 (O). Top panels show cell abundance $\left(10^{3}\right.$ cells $\left.\mathrm{ml}^{-1}\right)$; middle panels show mean forward light scatter cell ${ }^{-1}$ (relative units); bottom panels show mean red fluorescence cell ${ }^{-1}$ (relative units) 

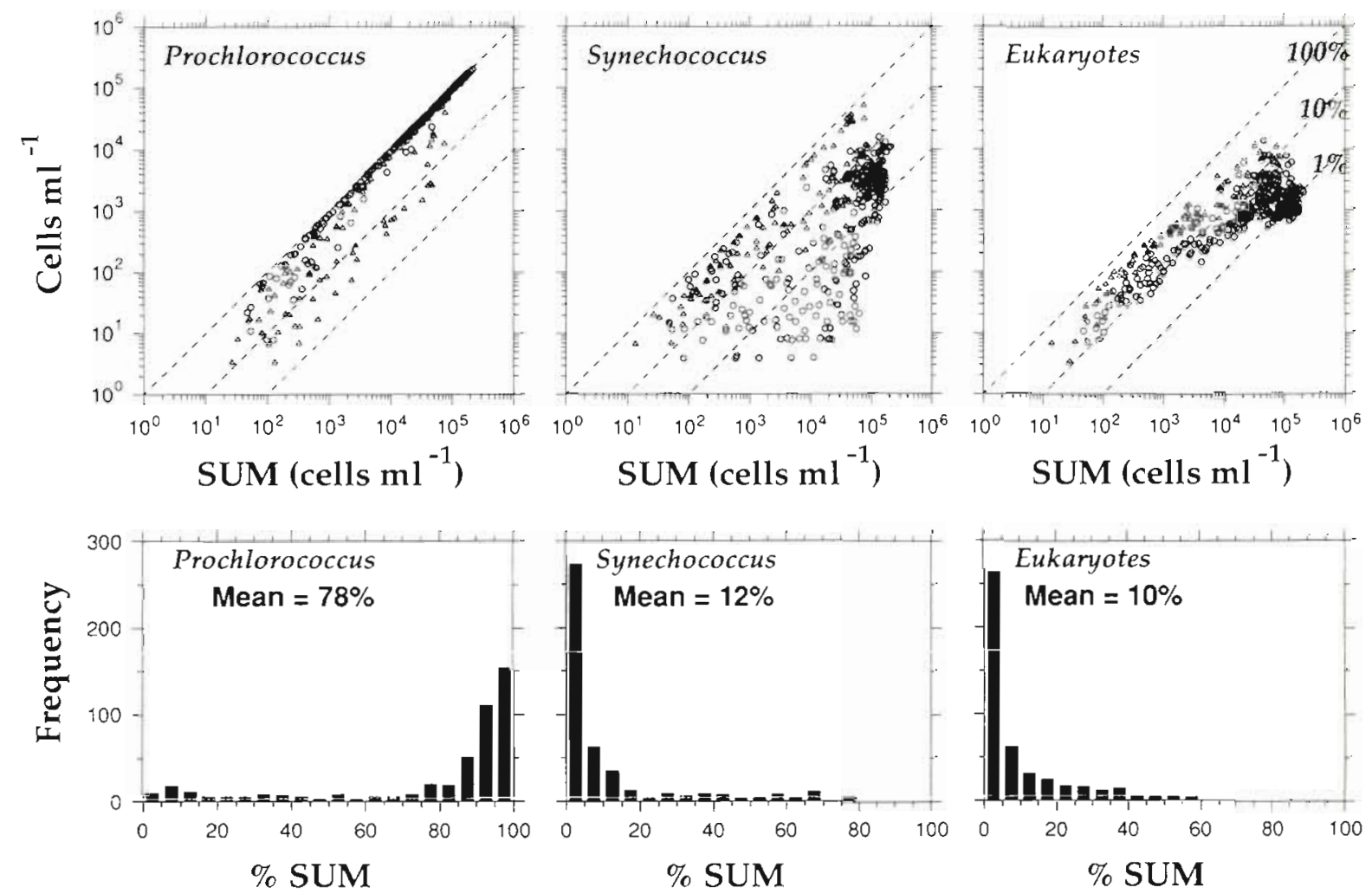

Fig. 4. Prochlorococcus spp., Synechococcus spp., and eukaryotic algae. Contribution to total ultraphytoplankton expressed in cell abundance $\mathrm{ml}^{-1}$ seawater. Top panels show the scatter relationship between each group and sum of the 3 groups; circles: 1992 samples, triangles: 1993 samples. Dashed diagonal lines indicate 100, 10 and $1 \%$ of the sum. Bottom panels show frequency distributions of the percentage contribution by each group to the sum (SUM). Mean percentage for each group is indicated and was calculated from the entire data encompassing all depths and both years

available measures on which to establish a ranking: cell numbers, carbon biomass, chlorophyll biomass, and primary productivity. For cell numbers, a simple indicator is:

$$
\frac{n_{i}}{\sum_{i} n_{i}}
$$

where $n$ is abundance (cells $\mathrm{ml}^{-1}$ ) and $i$ refers to Prochlorococcus, Synechococcus, or eukaryotic ultraplankters. Over the entire data set pooled from all depths and both seasons, the mean composition by numbers was $78 \%$ Prochlorococcus, $12 \%$ Synechococcus, and $10 \%$ eukaryotes (Fig. 4).

For carbon biomass, the indicator is based on the weighted measurement of mean light scatter per cell $\left(\overline{s_{i}}\right)$ which is assumed to be a substitute for mean cell carbon (Li 1994a):

$$
\frac{n_{i} \times \overline{s_{i}}}{\sum_{i} n_{i} \times \overline{s_{i}}}
$$

The product of $n_{1}$ and $\overline{s_{1}}$ signifies total light scatter in unit volume seawater due to ultraphytoplankton group i. On this basis, the pooled data indicate a distribution of $11 \%$ Prochlorococcus, $2 \%$ Synechococcus, and $87 \%$ eukaryotes (Fig. 5).

Similarly, for chlorophyll biomass, the indicator is based on the weighted measurement of mean red fluorescence per cell $\left(\overline{f_{i}}\right)$ which is assumed to be a substitute for mean cell chlorophyll (Li 1994a):

$$
\frac{n_{1} \times \overline{f_{i}}}{\sum_{i} n_{1} \times \overline{f_{i}}} .
$$

The product of $n_{i}$ and $\overline{f_{i}}$ signifies total fluorescence in unit volume seawater due to ultraphytoplankton group i. On this basis, the pooled data indicate a distribution of $28 \%$ Prochlorococcus, $11 \%$ Synechococcus, and $61 \%$ eukaryotes (Fig. 6).

For primary productivity, the indicator is based on the actual measurement of ${ }^{14} \mathrm{C}$ uptake rate per cell $\left(p_{i}\right)$ obtained by flow sorting (Li 1994b):

$$
\frac{n_{1} \times p_{1}}{\sum_{1} n_{1} \times p_{i}}
$$



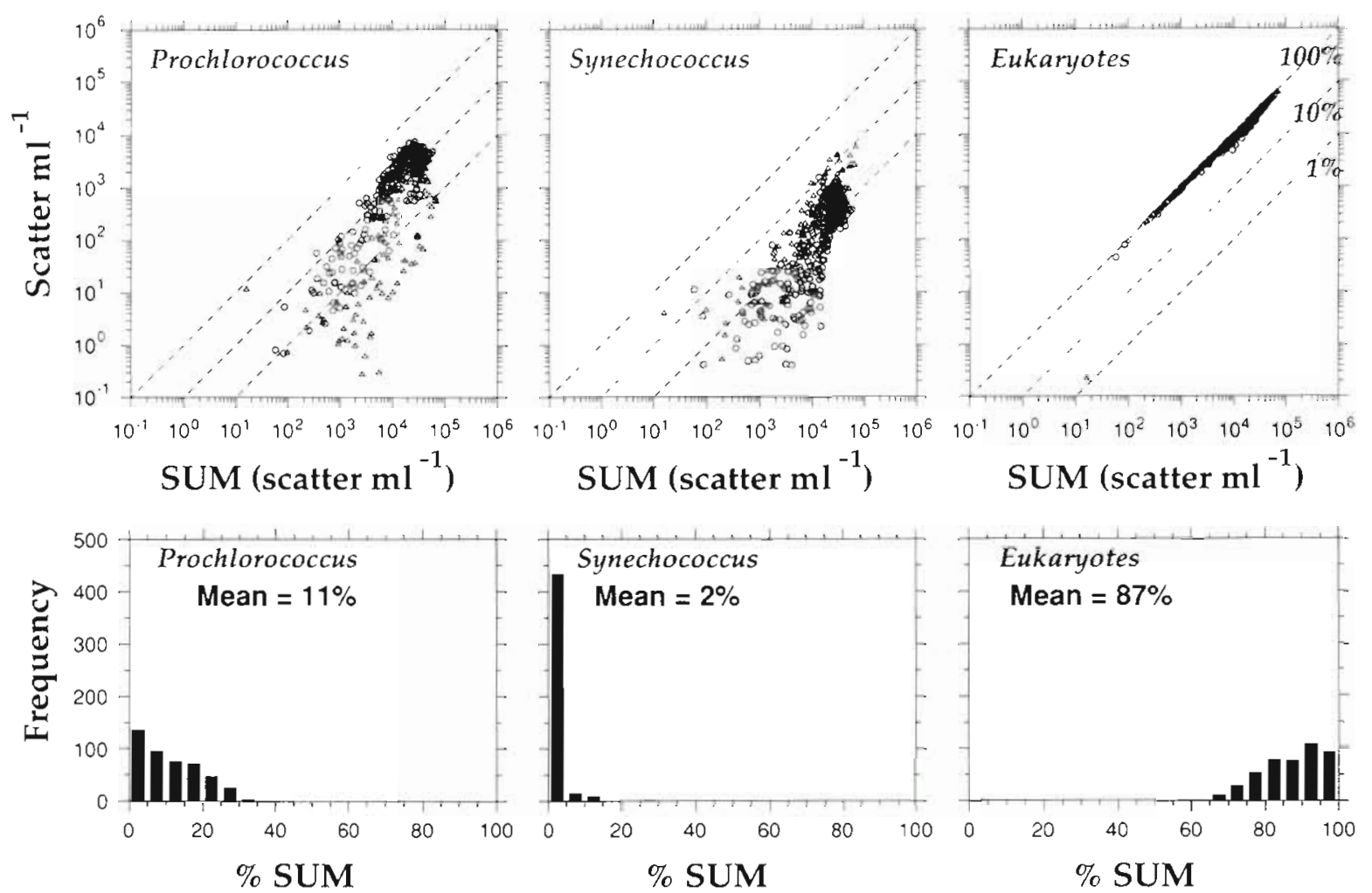

Fig. 5. Prochlorococcus spp., Synechococcus spp., and eukaryotic algae. Contribution to total ultraphytoplankton expressed in total light scatter $\mathrm{ml}^{-1}$ seawater. See Fig. 4 for further explanations
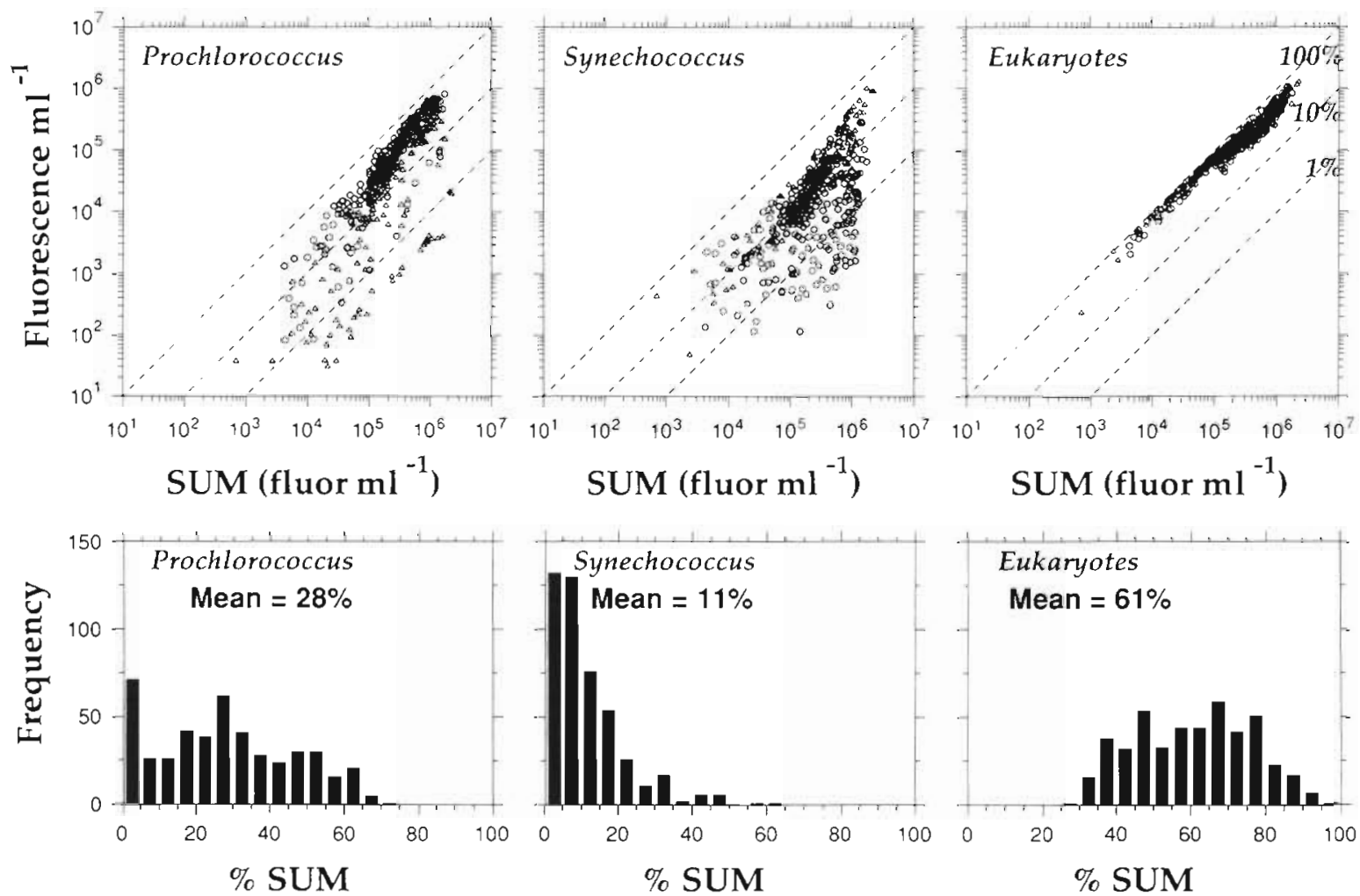

Fig. 6. Prochlorococcus spp., Synechococcus spp., and eukaryotic algae. Contribution to total ultraphytoplankton expressed in total red fluorescence (fluor) $\mathrm{ml}^{-1}$ seawater. See Fig. 4 for further explanations 

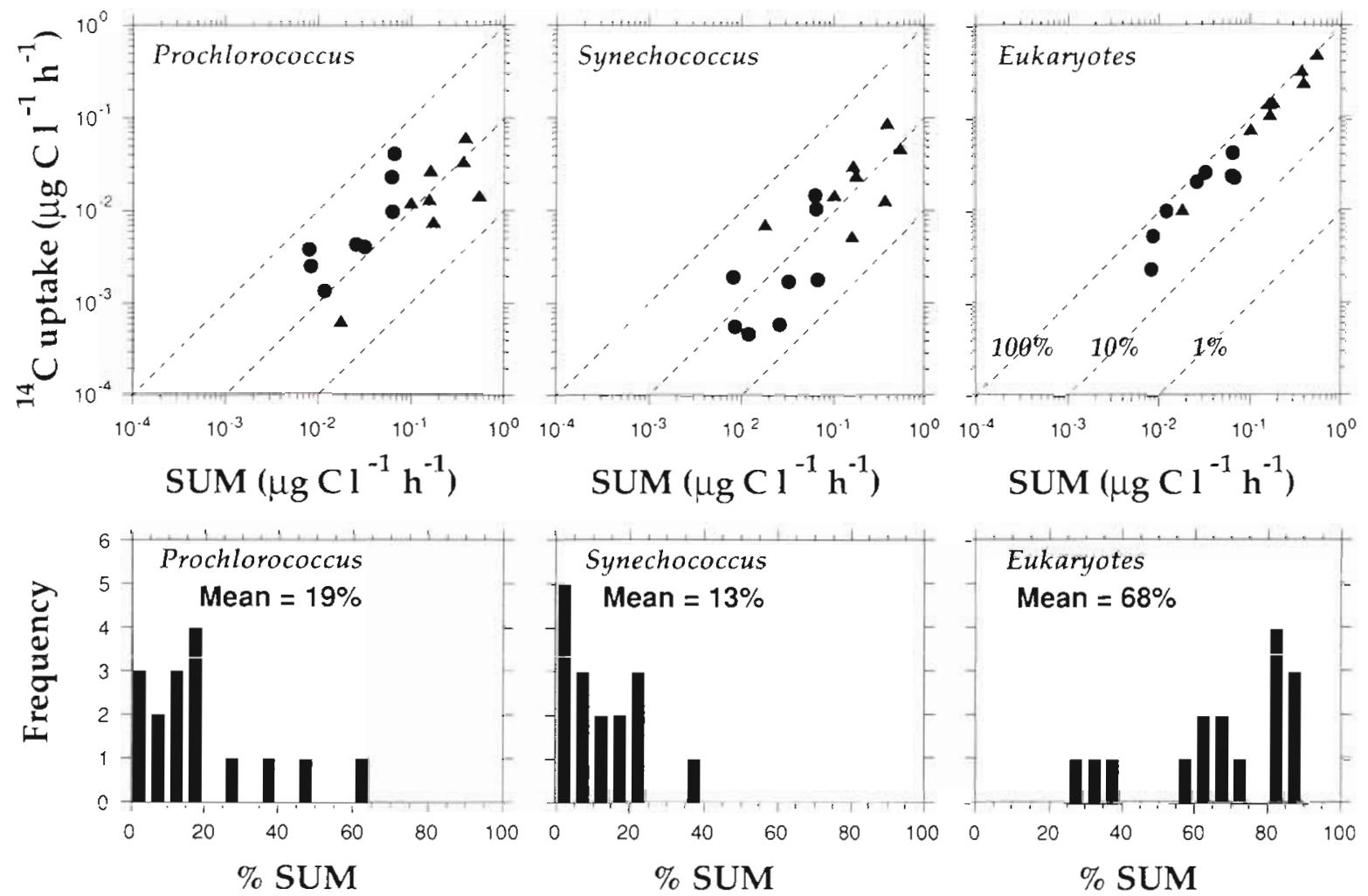

Fig. 7 Prochlorococcus spp., Synechococcus spp., and eukaryotic algae. Contribution to total ultraphytoplankton expressed in rate of ${ }^{14} \mathrm{C}$ uptake $\mathrm{ml}^{-1}$ seawater. See Fig. 4 for further explanations

The product of $n_{i}$ and $p_{i}$ is the ${ }^{14} \mathrm{C}$ uptake rate in unit volume seawater due to ultraphytoplankton group $i$. On this basis, the pooled data indicate a distribution of $19 \%$ Prochlorococcus, $13 \%$ Synechococcus, and $68 \%$ eukaryotes (Fig. 7).

These results can be summarized as follows. In the central North Atlantic, at most depths in either of the seasons in question, Prochlorococcus were almost always the most abundant ultraphytoplankter; however, the major portion of ultraplankton biomass and productivity was usually attributable to the eukaryotic cells.

Three lines of independent evidence are available to corroborate the results presented here. First, when carbon biomass of each group is estimated on the basis of cellular carbon content implied by cell size, rather than on the basis of flow cytometric light scatter, the same conclusion is reached, i.e. that eukaryotes dominate the ultraphytoplankton in the North Atlantic (Li \& Wood 1988, Li et al. 1992, 1993a), in the equatorial Pacific (Eppley et al. 1992), and in the subarctic Pacific (Booth et al. 1993). Further, DuRand et al. (1994) determined that nanophytoplankton (mostly 2 to $5 \mu \mathrm{m}$ cells) made the greatest contribution, via light scattering, to changes in beam attenuation which is a bulk optical property of seawater
Second, when chlorophyli biomass of Prochlorococcus is estimated from the concentration of divinyl chlorophyll $a$ which is a chemotaxonomic marker for this genus, the average percentage contribution to total chlorophyll $a$ is $29 \%$ in the Sargasso Sea (Goericke \& Repeta 1993, Goericke \& Welschmeyer 1993), comparable to the present mean value of $28 \%$ for Prochlorococcus fluorescence (Fig. 6). In spite of the close similarity in these percentages, it should be noted that if only the data of 1992 (when Prochlorococcus were more abundant) are considered, Prochlorococcus fluorescence represented $37 \%$ of the total fluorescence. This mean value is less than $49 \%$, which is the mean high performance liquid chromatography (HPLC)-measured contribution of divinyl chlorophyll a to total chlorophyll a over the central North Atlantic sampled in late summer 1992 (E. J. H. Head unpubl.). This discrepancy could be explained if the in vivo fluorescence yield per unit chlorophyll is less for Prochlorococcus than for other phytoplankton. There is some indirect evidence that this may be so ( $\mathrm{Li}$ et al. 1993b). Even if a high percentage is accepted for the contribution of Prochlorocccus to pigment biomass (particularly in late summer), the eukaryotic ultraplankton remain a very significant component throughout the year. 
A third aspect is the consideration of primary productivity. Two independent methods for estimating Prochlorococcus productivity yield percentage contributions similar to the present mean value of $19 \%$ (Fig. 7). In one method, Prochlorococcus productivity was measured by the incorporation of ${ }^{14} \mathrm{C}$ into divinyl chlorophyll a (Goericke \& Welschmeyer 1993), and approximately $25 \%$ of total productivity was ascribed to this genus in the Sargasso Sea. In a second method, Prochlorococcus productivity was estimated from cell cycle analysis of DNA frequency histograms (Vaulot et al. 1994), and from 7 to $19 \%$ of total productivity was ascribed to this genus in the equatorial Pacific.

In the central North Pacific at station ALOHA near Hawaii, which typifies the subtropical open ocean, the abundance structure of the ultraphytoplankton assemblage is most extremely dominated by Prochlorococcus. There, the depth-integrated abundances $\left(10^{6}\right.$ cells $\mathrm{cm}^{-2}$ ) are about 2000 for Prochlorococcus, 15 for Synechococcus, and 15 for eukaryotes (Campbell \& Vaulot 1993). This situation corresponds to a distribution of phytoplankton carbon biomass of $64 \%$ Prochlorococcus, $4 \%$ Synechococcus, and $32 \%$ eukaryotic algae (Campbell et al. 1994a). The percentage of chlorophyll a represented by the prochlorophyte marker divinyl chlorophyll $a$ is also dominant at ALOHA, being $70 \%$ at the deep chlorophyll maximum layer (Letelier et al. 1993). Furthermore, Prochlorococcus at ALOHA. accounts for a higher mean percentage (44\%) of total productivity than elsewhere studied (Vaulot 1995). It thus appears that when Prochlorococcus abundance reaches (Campbell \& Vaulot 1993) or exceeds (Veldhuis \& Kraay 1993) about 200000 cells $\mathrm{ml}^{-1}$, the biomass and productivity of this genus become very significant or even dominant. This was not the case observed in the 2 transatlantic transects.

Eukaryotic ultraphytoplankters are extremely diverse in a taxonomic sense (Hooks et al. 1988, Campbell et al. 1994b), but many of them are flexible enough to pass through membrane filter pores smaller than the cell diameter (Shapiro \& Guillard 1986). The number and diversity of cells found in the filtrate of $2 \mu \mathrm{m}$ Nuclepore membrane are very similar to the number and diversity in unfiltered seawater along these North Atlantic transects (Li 1994). Although measurements of size-fractionated chlorophyll or ${ }^{14} \mathrm{C}$ uptake rate often indicate large contributions from the picoplankton $(<2 \mu \mathrm{m})$ to total phytoplankton, such measurements are unable to partition the biomass and productivity amongst Prochlorococcus, Synechococcus, and eukaryotic algae. In this regard, the apparent dominance of eukaryotes in the ultraplankton of the North Atlantic means that this taxonomically diverse assemblage is a crucial determinant of the carbon flux in this oceanic region.
Acknowledgements. This work is a contribution to the Canadian JGOFS programme and was supported by the following Canadian government organizations: Department of Fisheries \& Oceans, Department of National Defense, Canadian Panel on Energy R\&D (PERD), and the interdepartmental 'Green Plan' Other support was provided by the Joint Research Centre, Commission of the European Communities.

\section{LITERATURE CITED}

Booth BC, Lewin J, Postel JR (1993) Temporal variation in the structure of autotrophic and heterotrophic communities in the subarctic Pacific. Prog Oceanogr 32:57-99

Campbell L, Nolla HA, Vaulot D (1994a) The importance of Prochlorococcus to community structure in the central North Pacific Ocean. Limnol Oceanogr 39:954-961

Campbell L, Shapiro LP, Haugen E (1994b) Immunochemical characterization of eukaryotic ultraplankton from the Atlantic and Pacific Oceans. J Plankton Res 16:35-51

Campbell L, Vaulot D (1993) Photosynthetic picoplankton community structure in the subtropical North Pacific Ocean near Hawaii (station ALOHA). Deep Sea Res 40: 2043-2060

DuRand MD, Olson RJ, Zettler ER (1994) Flow cytometric analysis of phytoplankton growth during diel studies in the equatorial Pacific. EOS 75:28-29

Eppley RW, Chavez FP, Barber RT (1992) Standing stocks of particulate carbon and nitrogen in the equatorial Pacific at $150^{\circ} \mathrm{W}$. J geophys Res 97:655-661

Goericke R, Repeta DJ (1993) Chlorophylls $a$ and $b$ and divinyl chlorophylls $a$ and $b$ in the open subtropical North Atlantic Ocean. Mar Ecol Prog Ser 101:307-313

Goericke R, Welschmeyer NA (1993) The marine prochlorophyte Prochlorococcus contributes significantly to phytoplankton biomass and primary production in the Sargasso Sea. Deep Sea Res 40:2283-2294

Goldman JC (1988) Spatial and temporal discontinuities of biological processes in pelagic surface waters. In: Rothschild BJ (ed) Toward a theory on biological-physical interactions in the world ocean. Kluwer Academic Publishers, p 273-296

Hooks CE, Bidigare RR, Keller MD, Guillard RRL (1988) Coccoid eukaryotic marine ultraplankters with four different HPLC pigment signatures. J Phycol 24:571-580

Letelier RM, Bidigare RR, Hebel DV, Ondrusek M, Winn CD, Karl DM (1993) Temporal variability of phytoplankton community structure based on pigment analysis. Limnol Oceanogs 38:1420-1437

Li WKW (1994a) Phytoplankton biomass and chlorophyll concentration across the North Atlantic. Scientia mar 58: $67-79$

Li WKW (1994b) Primary production of prochlorophytes, cyanobacteria, and eucaryotic ultraphytoplankton: measurements from flow cytometric sorting. Limnol Oceanogr 39:169-175

Li WKW, Dickie PM, Harrison WG, Irwin BD (1993a) Biomass and production of bacteria and phytoplankton during the spring bloom in the western North Atlantic Ocean. Deep Sea Res II 40:307-327

Li WKW, Dickie PM, Irwin BD, Wood AM (1992) Biomass of bacteria, cyanobacteria, prochlorophytes and photosynthetic eukaryotes in the Sargasso Sea. Deep Sea Res 39: 501-519

Li WKW, Wood AM (1988) Vertical distribution of North Atlantic ultraphytoplankton: analysis by flow cytometry and epifluorescence microscopy. Deep Sea Res 35:1615-1638 
Li WKW, Zohary T, Yacobi YZ, Wood AM (1993b) Ultraphytoplankton in the eastern Mediterranean Sea: towards deriving phytoplankton biomass from flow cytometric measurements of abundance, fluorescence and light scatter. Mar Ecol Prog Ser 102:79-87

Margalef R (1994) Through the looking glass: how marine phytoplankton appears through the microscope when graded by size and taxonomically sorted. Scientia mar 58: $87-101$

Olson RJ, Chisholm SW, Zettler ER, Altabet MA, Dusenberry JA (1990a) Spatial and temporal distributions of prochlorophyte picoplankton in the North Atlantic Ocean. Deep Sea Res 37:1033-1051

Olson RJ, Chisholm SW, Zettler ER, Armbrust EV (1990b) Pigments, size, and distribution of Synechococcus in the North Atlantic and Pacific Oceans. Limnol Oceanogr $35: 45-58$

Olson RJ, Zettler ER, Anderson OK (1989) Discrimination of eukaryotic phytoplankton cell types from light scatter and

This article was submitted to the editor autofluorescence properties measured by flow cytometry. Cytometry 10:636-643

Olson RJ, Zettler ER, DuRand MD (1993) Phytoplankton analysis using flow cytometry. In: Kemp PF, Sherr BF, Sherr EB, Cole JJ (eds) Handbook of methods in aquatic microbial ecology. Lewis Publ, p 175-186

Shapiro LP, Guillard RRL (1986) Physiology and ecology of the marine eukaryotic ultraplankton. Can Bull Fish Aquat Sci $214: 371-389$

Vaulot DV (1995) Cell cycle analysis: prospects for estimating phytoplankton productivity. In: Joint IR (ed) Molecular ecology of aquatic microbes. Springer-Verlag, Berlin (in press)

Vaulot DV, Marie D, Partensky F (1994) Prochlorococcus divides once a day at the equator. $\operatorname{EOS} 75: 28$

Veldhuis MJW, Kraay GW (1993) Cell abundance and fluorescence of picoplankton in relation to growth irradiance and nitrogen availability in the Red Sea. Neth J Sea Res $31: 135-145$

Manuscript first received: September 29, 1994 Revised version accepted: February 8, 1995 